\title{
'A Nut We Have Officially yet to Crack': Forcing the Attention of Athletic Departments Toward Sustainability Through Shared Governance
}

\author{
Martin Barrett ${ }^{1, *}$, Kyle S. Bunds ${ }^{2}$, Jonathan M. Casper ${ }^{2}$, Michael B. Edwards ${ }^{2}$, \\ D. Scott Showalter ${ }^{3}(D)$ and Gareth J. Jones ${ }^{4}$ \\ 1 Department of Kinesiology and Recreation, Frostburg State University, Frostburg, MD 21532, USA \\ 2 Department of Parks, Recreation and Tourism Management, North Carolina State University, \\ Raleigh, NC 27695, USA; ksbunds@ncsu.edu (K.S.B.); jmcasper@ncsu.edu (J.M.C.); \\ mbedward@ncsu.edu (M.B.E.) \\ 3 Poole College of Management, North Carolina State University, Raleigh, NC 27695, USA; \\ dsshowal@ncsu.edu \\ 4 School of Sport, Tourism and Hospitality Management, Temple University, Philadelphia, PA 19122, USA; \\ gareth.jones@temple.edu \\ * Correspondence: mbarrett@frostburg.edu
}

Received: 19 June 2019; Accepted: 16 September 2019; Published: 23 September 2019

check for updates

\begin{abstract}
In many ways, intercollegiate athletics represents the 'sustainable' front porch of higher education. The high-visibility, high-impact nature of elite-level college athletics make athletic departments a central player in the sustainable development journey. However, not all athletic departments respond to this responsibility, nor are all responses uniformly successful. According to national reporting frameworks, an increasing number of universities in the United States are choosing to involve their athletic departments in university-level sustainability governance structures, but the benefits and limitations of this remain unclear. Using the theory of loosely coupled systems, and more specifically, the voice of compensations (which views loose coupling as an unsatisfactory state), the purpose of this paper is to explore perceptions of athletic department engagement in shared sustainability governance, and, thus, a whole-of-institution approach. Semi-structured interviews with sustainability office personnel were conducted and analyzed, and the findings imply that shared sustainability governance has the potential to focus the attention of athletic departments toward sustainability, as well as to reaffirm shared values. Yet, to maximize the impact of athletic departments toward the sustainable development goals of a university, sustainability office personnel suggest the deployment of additional change levers, in a multi-dimensional fashion, as supplementary coupling mechanisms. These would include more rigorous sustainability goals (top-down), continued collaboration on 'low-hanging fruit' initiatives (lateral), student-athlete engagement (bottom-up), and the development of an internal sustainability framework (inside-out).
\end{abstract}

Keywords: athletic departments; higher education; sustainability; loose coupling; shared governance; United States

\section{Introduction}

Executing strategy in universities is a complex matter, as the institutions themselves are likened to "multi-headed monsters, each with unique recipes for success" [1] (p. 28). Moreover, basic units within universities have fairly independent decision-making power over their activities [2], and freedom to self-determine policies and priorities [3]. In essence, complex organizations like universities display varying levels of coupling across a number of domains where interdependent elements vary 
in the number and strength of their interdependencies [4]. In fact, formal structures in educational organizations are understood as being decoupled from technical activities and outcomes as a means of maintaining support in a pluralistic environment [5]. Accordingly, some decisions in universities requiring specialized expertise (e.g., teaching and research) can only be made by individual professors, while others can come from central administrators as well as from collective and interactive processes [6]. Unsurprisingly, an extensive body of literature in higher education has focused on the contentious relationships between university administrators and faculty [7-10].

As an alternative and more contemporary example of coupling in United States higher education, a number of scholars note the widening financial and strategic chasm between universities and intercollegiate athletic departments [11-14]. For example, on one hand, universities who compete at the highest level of intercollegiate athletic competition regard their athletic departments as "'auxiliary activities', responsible for generating most of the revenue to cover their costs through ticket sales, licensing, and broadcasting contracts" [15] (p. 87). On the other hand, five out of every six of the top athletic departments successfully secure scarce general funding to intercollegiate sports through student fees [16]. On one hand, the very nature of intercollegiate athletics means athletic departments embody values and work towards goals that are different from academic units [15]. On the other hand, administrators leverage athletic programs to serve as the highly visible 'front porch' of universities [17]. Such antagonistic examples depict what Orton and Weick [4] define as a loosely coupled, rather than decoupled, context. As such, athletic departments, for all of their perceived autonomy, simultaneously demonstrate responsiveness and distinctiveness with the university writ large across multiple domains.

In the sustainability domain, previous empirical work has supported the willingness of athletic departments to prioritize [18,19] and adopt greener practices [20]. This greening movement within intercollegiate athletics follows an increasing number of universities worldwide that are recognizing the importance of sustainable development $[1,21]$ and aligning themselves with the principles of sustainability [22]. As such, sustainability in intercollegiate athletics demonstrates a level of responsiveness with the university more generally. Conversely, athletic departments are also utilizing their unique resources, such as high profile status and marketing platforms [18], to develop a more distinctive approach to sustainability efforts in comparison with other university departments and units. As a result, the simultaneous responsiveness and distinctiveness of athletic department sustainability action implies that the university-athletics relationship is, again, loosely coupled.

Loose coupling is often perceived as an unsatisfactory state that must be reversed, and this perspective is referred to as the voice of compensations [4]. In terms of corporate social responsibility more generally, Asif, Searcy, Zutshi, and Fisscher [23] suggest that managing stakeholder interests in isolation places pressure on organizational resources (e.g., personnel, time, and money), and leads to an ineffective use of such resources. Therefore, sustainability delivery is most effective within functionally integrative organizational structures [24], or tightly coupled systems. To compensate more generally for a lack of integration, calls for greater accountability in higher education have facilitated a move toward tight coupling and narrow control [25], which has been accompanied by frequent shifts in governance arrangements [26]. In the sustainability domain, it is at the organizational level where the charge is to create and establish campus-wide policies, objectives, and targets as well as prove the main decision-making function [27], and, thus, compensate for the lack of integration across the institution as a whole. To this end, Adams [28] puts forward a framework for managing sustainability in higher education, and these governance arrangements include a number of essential elements, including an empowered senior person responsible for sustainability, and a collaborative approach across senior leaders.

Athletic departments look to compensate for a lack of a coordinated and organized approach to sustainability through the creation of cross-functional 'green teams' $[18,19,29,30]$. Green teams are voluntary and formal collaborative arrangements between relevant internal and external stakeholders that can help advance an organization's sustainability initiatives [30]. Moreover, a green team is a planning and policy making team whose impact extends into organization operations and the external 
world of its stakeholders [29]. However, previous research suggests the capacity in which athletic departments serve on green teams as well as the exact mission of these teams remains unclear [18]. To date, there is a scarcity of research focusing on athletic department involvement, specifically in university-level sustainability planning and coordination. As a result, an opportunity exists to understand the perceived benefits of athletic department contributions to shared governance models.

The purpose of this study is to describe athletic department involvement in shared sustainability governance. Furthermore, the purpose of this study is supported by two specific research questions:

Research Question 1. How are universities forcing the attention of athletic departments toward sustainability through engagement in shared sustainability governance?

Research Question 2. How is athletic department engagement in shared sustainability governance compensating for loose coupling with the university overall?

Accordingly, this study examines sustainability governance at universities across the United States through semi-structured interviews with sustainability office personnel. The result is a better understanding of how governance mechanisms compensate for the loose coupling between athletic departments and the wider university system. The remainder of this paper is organized as follows. First, the context and background of strategic sustainability management in higher education and intercollegiate athletics is summarized. Then, the theoretical foundations are built through the perspective of loosely coupled systems and the role of shared governance as a coupling mechanism. The methods are then explained before a combined findings and discussion section is presented. Finally, the study concludes with practical implications and suggestions for future research.

\section{Research Context}

\subsection{Sustainability Management in Higher Education}

Universities are integrating sustainability as a core strategic principle across campuses [31] through the development and implementation of comprehensive plans for setting sustainability goals [32]. Arguably, this strategic commitment began in 2006, when 12 college and university presidents initiated the American College and University Presidents' Climate Commitment (ACUPCC) [33]. The ACUPCC ignited a sustainability movement with 400 schools making the commitment in the initial period of charter membership between December 2006 and September 2007 [34]. The commitment itself made clear the role higher education has in leading climate and sustainability action for the sake of students and society [33].

Universities and colleges have since taken significant green strides in demonstrating sustainability in practice, thanks in part to the 2008 Higher Education Sustainability Act and the establishment of the University Sustainability Grants Program [35]. More recently, the Association for the Advancement of Sustainability in Higher Education (AASHE), through their 2018 annual conference titled 'Global Goals: Rising to the Challenge', began championing the critical role higher education must play in achieving the United Nations Sustainable Development Goals. Accordingly, the role of universities in advancing sustainability is twofold: as an institution that needs to be changed and/or as a potential change agent [36]. For example, universities are adopting a number of infrastructural and operational business practices to reduce their ecological footprint. Such efforts include waste management strategies like recycling and composting [37] and the reduction of greenhouse gas emissions [38]. Additionally, universities are operationalizing their potential as sustainability change agents by integrating sustainability into the curriculum, student and faculty life, and the wider community [39]. However, in higher education's twofold sustainability responsibility, a tendency exists for universities to focus more so on how higher education can change internally [36]. Dyer and Dyer [40] claim this tendency is reinforced by the ACUPCC, which creates a framework wherein institutions commit to future successes in the form of climate neutrality, then backcast to the present before creating plans to move toward the desired future state. Salviono, Franzoni, and Casnna [41] consider university 
governance with such a limited propensity towards sustainability as an inefficient condition to promote change. In fact, while universities recognize their role in leading societal change toward a more sustainable world, many have not implemented whole-institution change [42].

To address limitations in university sustainability strategy, a number of frameworks exist to encourage best practice approaches to sustainability management in the higher education context. Adams [28] put forward a framework for managing sustainability in universities that includes a number of essential and desired elements. Among the essential elements are the visible support of a president/vice-chancellor and governing body, pro-active senior leadership, an empowered senior person responsible for sustainability, and a collaborative approach across senior leaders. Additional desirable elements in Adams' framework include an advisory board of external expertise, policies that incorporate sustainability, a stakeholder engagement strategy, and alignment with existing national quality frameworks. Epstein's [43] Corporate Sustainability Model considers drivers of sustainability performance (inputs), actions managers can take to affect performance (processes), and consequences of those actions (outputs). In terms of managerial actions, Epstein advocates the importance of committed leadership, strategy development, organizational design that embeds sustainability across all units, and the alignment of systems to coordinate activities and motivate employees. Such frameworks are warranted due to the proliferation of strategic approaches to sustainability at the university level, which is evidenced through emerging green campus indexes like The Princeton Review's 'Top 50 Green Colleges' and the Sierra Club's 'Cool Schools' ranking for the greenest colleges and universities.

\subsection{Sustainability Management in Intercollegiate Athletics}

In intercollegiate athletics, sustainability decision-making is highly differentiated between institutions. At the lower levels of intercollegiate athletic competition (i.e., Division III), sustainability decision-making is a function of an athletic director [19], whereas, at the elite level (Division I), decision-making occurs predominantly through associate athletic directors [18]. Yet, athletic department personnel can lack the environmental skills or training to make effective decisions [44], which necessitates a process of resource exchange in order for athletic departments to, at least, initiate sustainability projects. Often, and without a direct mandate from a higher administrative power, collaborative relationships develop through outreach from sustainability office personnel to the athletic department [44]. Such collaborative efforts are particularly effective in developing sustainability initiatives focusing on public external events (e.g., tailgate and facility/stadium recycling) [44]. Accordingly, not only are athletic departments somewhat reactive in their commitment to sustainability, but these collaborative efforts are predicated on interpersonal relationships as opposed to institutional commitments.

Where athletic departments are involved in structures beyond dyadic interpersonal ties (e.g., in green teams), the scope and remit of these groups show considerable variation. For example, of the two athletic departments involved in environmental committees in the Pfahl, Casper, Trendafilova, McCullough, and Nguyen [44] study, one is involved in a working group that "makes recommendations that are then filtered up to the athletics administration" (p. 40) and the other is a higher-level council comprising 20-25 campus units. Such variation is likely pervasive across the higher education sector. Casper, Pfahl, and McSherry [18] found $41 \%$ of Division I institutions had athletic department representation on campus-wide sustainability teams, while Casper and Pfahl [19] found 28\% of Division III institutions with similar involvement. Nevertheless, McCullough et al. [30] suggest that green teams provide a bridge with university-wide goals through formal, joint decision-making processes.

\section{Theoretical Background}

\subsection{Loosely Coupled Systems}

Any location in an organization, be it a department, unit, office, or working group, contains interdependent elements that vary in the number and strength of their interdependencies [4]. Moreover, 
these interdependent elements represent shared variables that influence the degree of interaction, or coupling, between specific locations within an organization or broader systems [45]. In other words, coupling refers to "the degree to which events within one part of a system are felt by other parts of that system" [46] (p. 245). Glassman [45] suggests that with coupling, two qualifying variables are necessary. First, coupling requires time to be isolated as a special variable, as any judgment on an organization or system is relevant only during a given interval of time. Second, provision must be made for the presence of interactions between variables of varying strengths. So, as opposed to being a dichotomizing concept, coupling has the flexibility to reflect complexity of organizations as living systems. For example, Orton and Weick [4] suggest that organizations can be tightly coupled (i.e., where they demonstrate responsiveness without distinctiveness), decoupled (i.e., where they demonstrate distinctiveness without responsiveness), or loosely coupled (i.e., where they demonstrate distinctiveness and responsiveness simultaneously).

Loose coupling allows organizations to "follow their idiosyncratic learning processes while retaining some degree of responsiveness" [47] (p. 1028). Importantly, Weick [48] presents educational organizations as loosely coupled exemplars and, in doing so, demonstrates the process by which soft structures guide the loose assemblages of diverse educational organizations (e.g., schools) to develop similar meanings across time. Specifically, Weick [48] depicts the relationship between a counselor's office and the principal's office, both of which retain some level of identity and separateness, but remain attached under the overarching umbrella of the school. Yet, Goldspink [49] suggests that educational reform within a loosely coupled context is incompatible with formal or bureaucratic control, and that different forms of management are necessary to realize their distinct advantages. As a result, higher education experiences frequent shifts in governance arrangements, including the reshuffling of authority and responsibilities [26]. In the context of United States higher education, calls for more accountability have contributed to a move toward tight coupling with narrow control [25].

The main advantage of loose coupling as a durable concept is summarized by Orton and Weick [4] in the following passage:

... loose coupling allows theorists to posit that any system, in an organizational location, can act on both a technical level, which is closed to outside forces (coupling produces stability), and an institutional level, which is open to outside forces (looseness produces flexibility).

However, Orton and Weick [10] suggest that the application of loose coupling is often confused. Specifically, organizational theorists succumb to not distinguishing between dialectical interpretation (i.e., based on the degrees of responsiveness and distinctiveness, organizations are either non-coupled, tightly coupled, or loosely coupled) and the unidimensional interpretation of loose coupling (i.e., loose coupling is the end point of a sliding scale between tightly coupled and loosely coupled).

\subsection{Shared Governance as a Compensation for Loose Coupling}

In response to the varied use of the concept, Orton and Weick [4] present a reconceptualization of loose coupling by identifying five distinct voices in the related literature. The voice of compensation suggests that loose coupling is an unsatisfactory condition that should be reversed [4]. Tierney and Minor [50] suggest attempts to tighten loose coupling within university settings centered around effective governance. Therefore, using a voice of compensation, governance arrangements present an opportunity to rectify loose coupling as an unsatisfactory condition through enhanced leadership, focused attention, and shared values [4]. Specifically, Orton and Weick [4] refer to the role of leadership (strong or subtle) in unifying goals, the role of targets in focusing attention, and the role of reaffirming shared values in rectifying losses in control.

Governance gives overall direction to an organization, and oversees and controls management actions through accountability and regulation [51]. As such, shared governance allows various groups of people a share in these key decision-making processes [52]. Shared governance also allows certain 
groups to exercise primary responsibility for specific areas of decision-making [52]. According to Lechuga [53], shared governance is a unique characteristic of the United States higher education system. Cramer and Mozlin [54] suggest the modern roots of shared governance in higher education stem back to the 1966 Joint Statement on Government of Colleges and Universities. More specifically, the joint statement defines the main campus constituents as the governing board members, administrators, faculty members, students, and other persons. Therefore, shared governance in higher education refers to the structures and processes through which these constituents participate in the development of policies, and in decision-making that affects the institution [55]. Bejou and Bejou [56] offer a similar definition and suggest that shared governance must focus on informed decision-making, transparency, and open lines of communication between and among all components of the university community, while highlighting the important need for accountability, mutual respect, and trust within this participatory system.

Lapworth [57] claims models of shared governance fall under one of two categories: corporate models, with a focus on governing bodies, and consensual models, which focus on the roles of others. Alternatively, Yanko, Hardt, and Bradstock [58] have identified four different models of shared governance: unit-based, councilor, administrative, and congressional (see Figure 1). In unit-based shared governance models, each unit establishes its own system, which therein creates multiple models within a single institution. In councilor models of shared governance, a coordinating council directs activities on a more aggregate, departmental level, and the unit councils replicate the coordinating council structure. In congressional models of shared governance, all staff belong to a congress, which draws direct comparisons to the federal government. Furthermore, in congressional models of shared governance, committees submit work to a 'cabinet' for approval. Finally, in administrative models of shared governance, separate practice and management structures exist, and a forum integrates the work of the councils overseeing these parallel structures.
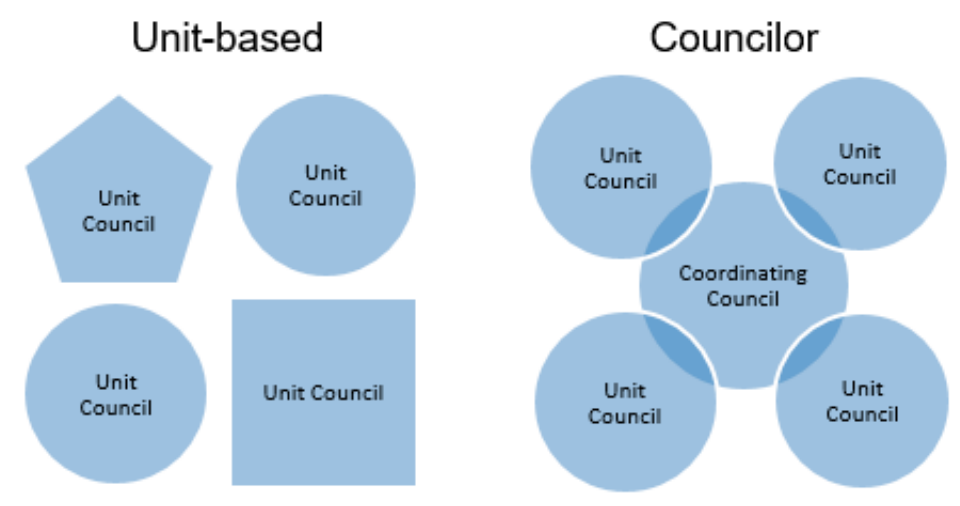

\section{Administrative}

Figure 1. Models of shared governance (adapted from Yanko et al. [58]).

Importantly, models of shared governance operate at different organizational levels, which influences extent of authority, decision-making, and participation [59]. Unit-based governance, intuitively, operates at the unit level. The unit level does, however, hold different meanings across varying organizational contexts. For example, for an institution such as a university or college, the unit can often denote the department, as opposed to an institution such as a hospital where the unit can be interpreted as a functional area or team. Yet, when governance is restricted to the unit-based level it is incompletely shared [60]. Alternatively, councilor and administrative models of shared governance operate at a more organizational level. Specifically within the context of higher education, it is at the organizational level where the charge is to create and establish campus-wide policies, objectives, and targets as well as to prove the main decision-making function [27]. The challenge with shared governance models is that organizations are complex and dynamic, which means that for these models to be effective they need to be diverse and flexible where individual institutions can adopt models to suit their character and needs [57]. 
Evidence exists to support the effectiveness of shared governance across various settings. Generally speaking, shared governance can reduce information asymmetry [61], promote a common understanding of goals, help prevent misunderstandings [62], and assist in coordinating goals and skills between partners [63]. Additionally, Bstieler, Hemmert, and Barczak [64] suggest that shared governance can be a bonding mechanism that helps partners to adapt to new circumstances-for instance, in the context of this study, an emerging organizational priority such as sustainability. In the context of nursing, which is where much of the literature of shared governance exists, outcomes of moving to a governance model include improved financial performance, employee satisfaction, and retention [65]. For university-industry partnerships, evidence points to the importance of shared governance and intellectual property policies as significant facilitators of trusting relationships and successful outcomes [66]. Moreover, Bstieler et al. [63] interpret trust formation as an outcome of parties collectively working through challenges, negotiating mutual adaptations, and making project-related decisions.

Considering how sustainability delivery is most effective within functionally integrative organizational structures [24], an opportunity exists to deductively combine the theory of loosely coupled systems and the concept of shared governance in the context of higher education sustainability. Adams' [28] framework for managing sustainability in universities posits effective sustainability integration as an outcome of a collaborative approach. Adams' framework also posits effective sustainability integration as dependent on the senior person responsibility for sustainability being empowered to lead. The juxtaposition of a collaborative approach with the empowerment of individuals to make decisions renders Adams' framework consistent with how Olson [52] understands the role of shared governance in decision-making. Together, shared governance and effective sustainability integration provide a relevant analytical framework to understand the exact types of sustainability governance structures to which athletic departments are involved. Shared governance also yields a number of benefits such as reducing asymmetry [61], promoting common understanding [62], and facilitating coordination [63], which are all means by which systems become increasingly coupled. Therefore, in understanding shared governance as a compensation for loose coupling, these concepts offer a basis for analyzing the benefits of involving athletic departments in such structures.

\section{Methods}

\subsection{Research Design}

This study applied a descriptive research design to establish a "relatively concrete description" [67] (p. 1) of athletic department involvement in organizational-level models of shared sustainability governance. The uncertainty surrounding athletic department involvement in models of shared governance beyond the unit level justified a descriptive research design with the multi-faceted goal of describing situations and events, examining why patterns in these situations and events exist, and determining what these patterns imply [68]. Participant interviews were used as the primary research method. Specifically, the participant interviews followed a semi-structured format, which allowed for interviews to cover the same topics along with some flexibility to probe other related topics [69]. The semi-structured interviews enabled the elicitation of subjective experiences relating to athletic department involvement in shared sustainability governance.

\subsection{Study Population}

For this study, the population comprised degree-granting institutions in the United States committed to advancing sustainability, which also included a National Collegiate Athletic Association (NCAA)-affiliated athletic program. To access this population, sampling was restricted to universities participating in the AASHE Sustainability Tracking, Assessment and Rating System (STARS), which is a transparent, self-reporting framework for colleges and universities to measure their sustainability performance. Furthermore, STARS is considered "the singular consensus-based tool for use by colleges 
and universities" [70] (p. 100), and all completed reports are publicly accessible online. In December 2018 , at the time of sampling, 228 universities out of a total of 1027 active STARS participants met the inclusion criterion of having an active report at the Bronze level or higher and a NCAA affiliated athletic program. A further review of STARS reports identified the number of universities who involve their athletic departments in organizational-level models of shared sustainability governance. Specifically, involvement was understood through responses within the 'PA-1: Sustainability Coordination' credit category where universities were asked to list sustainability committee members, to which a total of 32 institutions emerged. Figure 2 outlines the steps taken to arrive at a target population. [71]

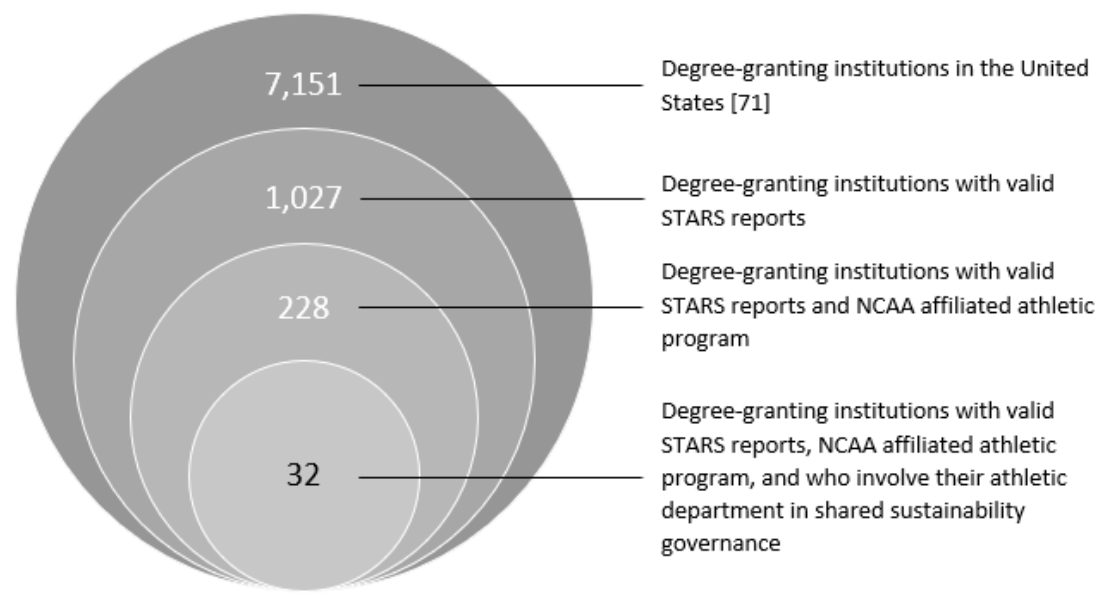

Figure 2. Target Population.

Furthermore, the target population included a majority of public institutions (22 public and 10 private) with NCAA Division I athletic programs (28 Division I, two Division II, and two Division III) and STARS certification at the Gold level (19 Gold and 13 Silver).

\subsection{Data Collection}

Semi-structured interviews were conducted with university sustainability personnel from 12 of the 32 universities identified in the target population. The sample of 12 universities was approximately representative of the target population with a majority of public institutions (10 public and two private), NCAA Division I athletic programs (11 Division I and one Division II), and STARS certification at the Gold level (seven Gold and five Silver). The institutions were sampled using non-specific emphasis with an opportunistic strategy [72]. First, the researchers took advantage of the network of sustainability practitioners at their host institution and sought participants by asking these practitioners to facilitate introductions with peers at institutions within the target population, which yielded five research participants. Second, the researchers made contact with all of the remaining institutions by phone or e-mail with a view to securing additional research participants. The recruitment of research participants conformed to a number of protective principles, which were vetted by the institutional review board at the lead author's host institution, including the right to participate and cease participation, the full disclosure of the study context, and the right to privacy [73]. Ultimately, the sample of 12 enabled a point of data saturation in which the ability to obtain additional new information was attained [74].

The justification for using sustainability office personnel as interview participations was based on their knowledge of and experience with the phenomenon of interest [75]. Specifically, the frequent interactions of sustainability office personnel with shared sustainability governance furnished them with the subjective knowledge from which to construct a descriptive understanding of the situation. While 12 institutions were sampled, 13 participants agreeing to be interviewed (i.e., two representatives from the same institution agreed to participate in a joint interview). Of these 13 participants, seven held positions at the director level, three at the coordinator level, one at the manager level, one at the officer level, and one held a title of assistant to a senior administrative officer. Interviews were 
conducted via telephone and lasted on average 25 minutes each. All interviews were conducted over a four-week period across the months of February and March 2019.

The interview guide was developed using the literature on sustainability management in higher education, loosely coupled systems, and shared governance. Specifically, the interview guide was separated into two parts in line with the two research questions. For example, the essential and desired elements of Adams' [28] framework for managing sustainability in higher education guided a number of questions in the interview guide relating to exactly what structures athletic departments were engaged in. Similarly, the benefits of shared governance (see [48-51]) guided the questions relating to how the interview participations perceived athletics to benefit from engagement in shared sustainability governance structures, which were also framed using the voice of compensations [4]. As such, the interview guide made use of direct and indirect questioning. The use of indirect questioning was seen as a key strategy for ensuring data credibility through informant honesty [76], which helped mitigate the effects of social desirability bias [77] by asking the participants (sustainability office personnel) to respond from the perspective of another group (athletic department). Furthermore, credibility was sought through a process of early familiarity with the culture of participating organizations [76], which included a broader review of each institution's STARS report and other relevant strategic documents posted online.

\subsection{Data Analysis}

Interviews were transcribed by the researchers and converted to a text format, which generated 41 single-spaced pages of data. Data analysis was guided by an analytical framework derived from literature on sustainability management in higher education, loosely coupled systems, and shared governance. To start, the researchers used the two primary research questions as a basis for structural coding, which allowed for further coding based on comparable segments [78]. Next, both data segments underwent a process of thematic analysis in keeping with Braun and Clarke's [79] methods, which allowed for the researcher to play an active role in the creation of themes in the data. For the first data segment, elements of Adams' [28] framework for managing sustainability in higher education along with Olson's [52] characteristics of shared governance were used as a coding frame from which to categorize athletic department involvement in shared sustainability governance structures. For the second data segment, the coding frame was derived from the literature on loosely coupled systems as well as the benefits of shared governance (i.e., trust, bonding, reducing asymmetry, goal coordination, etc.). Finally, the data segment relating to the second research question underwent descriptive coding, which was intended to augment and build off the deductive analytical framework to capture any unexpected topics.

The coding of transcripts was conducted using NVivo 12 software.

\section{Findings and Discussion}

The findings and discussion section is divided into four sub-sections. First, the shared sustainability governance engagement is discussed, which not only covers how athletic departments come to be involved, but also what systems of shared sustainability governance athletic departments are becoming involved in specifically, why they are involved at this level, and who is representing athletic departments on shared governance coordinating councils. Second, the compensatory outcomes of athletic department involvement in shared sustainability governance are discussed with a particular focus on how shared governance is facilitating tighter coupling. Third, the limitations of shared sustainability governance as a coupling mechanism are presented. Fourth, the limitations of the study are discussed.

\subsection{Engaging Athletics in Shared Sustainability Governance}

The respondents described shared sustainability governance within higher education mostly as interactions among and between either departments or subunits of departments. For example, one 
respondent described the coordinating council for sustainability as having "representation from across the institution" and "every department and business unit". However, what is also evident is interactions between departments and individuals who represent ideas and intentions. Specifically, in referring to the representation of the coordinating council for sustainability, another respondent stated:

It's primarily staff, facilities, campus planning and development, academic affairs, so the deans of all of the colleges on campus or their designate is represented, and then a representative from housing and residential life, and then those students who are designate environmental senators serve on the committee along with a handful of other students that have various roles on campus.

Shared sustainability governance appears to reflect departmental interactions through the interactions between individuals who represent those departments. On one hand, shared sustainability governance calls for representative involvement, rather than total, which is a logistical necessity considering the vastness of university campuses. However, on the other hand, the presence of individuals representing ideas and intentions also appears to be a matter of organizational structure and hierarchy. As an example, one respondent described how the coordinating council included a president, directors, faculty, and students. In other words, the president and directors represent their particular position and directorates by way of seniority, whereas faculty and student members of the shared sustainability governance system likely represent their colleagues and peers through a personal or professional interest in the subject matter.

Further context provided by the respondents into the decision-making authority of the coordinating council reveal some variation in committee purpose and function. Some sustainability office personnel discussed their coordinating council as an entity that drives campus sustainability strategy through the identification of very specific areas for the university to target, which is consistent with Orton and Weick's [4] claim that a careful selection of targets can compensate for loose coupling. As an example, one respondent shared how the coordinating council "weighed in heavily" on a number of campus issues, which also highlights how the coordinating council leverages an enhanced leadership status to influence other organizational levels and components [4]. Furthermore, another respondent shared how the university has been using the coordinating council "as governance for decisions as we move forward," which involved having input into changing university-wide goals as well as making changes to the campus sustainability plan.

However, some coordinating councils play a less authoritative role in campus sustainability matters. For example, one respondent described the purpose of the council as a "sounding board and a vetting entity" for the initiatives of the office of sustainability, while another described the role of the council to advise the administration on what can be done around sustainability. As a result, some shared sustainability governance systems reflect a more typical definition of shared governance that includes a balance between corporate and collegial approaches [53], and between participatory and primary decision-making responsibilities [52]. Alternatively, other systems appear to have less of an orientation around accountability, whereby efforts simply look to facilitate purposeful behavior towards the attainment of a goal or final state [80].

First and foremost, the justification for including athletic departments in shared sustainability governance is a matter of visibility. For example, according to one respondent, athletics is "the public face of the university". More specifically, another respondent claimed athletics to be "one of the most visible activities for any university that has Division I athletics". The high visibility of athletics in these universities presents an opportunity for sustainability to engage new audiences, which, according to one respondent, includes a "broad brush of stakeholders that traditionally the university research outcomes would not necessarily reach". As such, intercollegiate athletics occupies a unique position as a university department, which another respondent made clear by suggesting how "people have an affinity to the university as a result of athletics" and that "if anyone is going to help with promoting sustainability and creating outreach and awareness, athletics is a big component of that". 
Subsequently, athletics provides a very public gateway for various stakeholders to gain a sense of the university's commitment to sustainability. As one respondent stated, "athletics has become the face of sustainability in many ways". This respondent further elaborated on this connection with the following statement:

I liken this to a job I had in the private sector where we were committed to sustainability, but it didn't have a face until we tied it to one of the more popular products. Once we tied sustainability to athletics that gave us a front door to open conversations with a number of different stakeholders.

Skyttner [81] contends that the introduction of an input that is both unique and time critical may permit a semi-organized system to organize itself and to grow. In essence, the introduction of athletics as an input into the sustainable development journey of the university has had a similar effect. Furthermore, the majority opinion of sustainability office personnel suggests how athletic departments possess the potential to leverage their position as the 'front porch' of the university [17] to become the 'sustainable front porch'. As one respondent stated that "certainly how the public sees us it's really vital", and continued on to elaborate that, proportionately, "... even a smaller initiative in athletics could make a big difference". Ultimately, athletic departments serve in a sustainability ambassadorial role on university campuses.

Second, some shared sustainability governance systems involve their athletic departments, and simultaneously exclude other departments on campus, due to athletics' status as a high-impact partner. For example, one respondent considered intercollegiate athletics to be "a major function of the university". More specifically, another respondent claimed:

Athletics has two primary areas where they overlap with sustainability-one is greenhouse gas emissions, and the other is materials.... So by engaging the Athletics Director we are reaching an important subset of campus that is having an impact in those sustainability areas.

Moreover, this impact according to another respondent includes a "big role" within waste production and resource consumption. As such, combining high visibility with a high impact as grounds to include athletics in shared sustainability governance helps universities in their quest to meet their twofold sustainability responsibility, which Stephens, Hernandez, Román, Graham, and Scholz [36] describe in terms of sustainable operational change and sustainability change promotion.

Despite the compelling case for the inclusion of athletics in coordinating councils, much variation exists in exactly who represents the athletic department at this level. At one university, the sustainability office representative identifies the Athletic Director as the coordinating council appointee for athletics, but, in the same breath, explains how appointees are free to delegate who actually attends the formal meetings. A number of other sustainability office personnel have shared how coordinating council representation sits with the Director of Athletics, which is somewhat contradictory to how Casper et al. [18] present sustainability decision-making within Division I programs as occurring predominantly at levels below that of the Athletics Director. However, in other cases, athletic department representation has taken the form of a more facilities-based approach (e.g., Director of Facilities, Director for Internal Operations, Stadium Manager, etc.). In the case of the latter, athletic department representation in shared sustainability governance potentially falls foul of how Stephens et al. [36] claim universities often focus disproportionately on the way higher education can change internally, rather than realizing the potential of higher education as a sustainability change agent.

While athletic department representatives appear to vary across campuses in title, seniority, and role, the rationale for appointment or identification of representatives shares much similarity across different contexts. Specifically, personal interest, experience, and passion for sustainability often provide a justifiable means for inclusion in the coordinating council. For example, one respondent described how "a personal interest in sustainability" is useful "no matter what role you have". Likewise, another respondent described their athletics representative as someone who "was familiar with LEED 
[Leadership in Energy and Environmental Design, green building rating system] and sustainability initiatives in general" and who "came in a few years ago, kind of charged, fired up about those kinds of ideas".

In terms of how these athletic department representatives become involved in shared sustainability governance, some athletics representatives are appointed, while others become involved voluntarily. As an example, one respondent described the process of appointment, and stated that "every year the executive vice president comes up with a list of new [coordinating council] members and we do that in conversation with the committee co-chairs". Another respondent discussed how the appointment of representatives helps create a routine, which, in turn, "helps to make sure they are attending our meetings and are engaged in our sub-committees and working groups". Yet, such efforts demonstrate what Orton and Weick [4] consider to be focused attention, whereby sustainability office personnel who are empowered by senior accountable officers are forcefully creating orderly contingencies among university departments and campus constituents.

Alternatively, athletic department representatives are sometimes groomed for voluntary coordinating council involvement through their prior involvement in on-the-ground sustainability initiatives. For example, one respondent described the following scenario:

So we did have someone within athletics two years ago who had more experience working with green athletic programs at other universities. He helped us to implement green soccer games, we connected him with our composting and catering on campus, and worked really hard to make sure there was as little waste at games as possible.

Therefore, the typical approach appears to focus on engaging representatives who already have a basic knowledge and awareness of sustainability. Furthermore, just as Pfahl et al. [44] identify how collaborative processes are initiated by sustainability office personnel, the identification of suitable coordinating council representatives from within athletics often lies with the sustainability office.

Regardless of the nature of the forceful attention applied by systems of shared sustainability governance, sustainability office personnel emphasize the importance of formalizing the commitment beyond the level of the individual. For example, as one respondent claimed that "it is very important to find ways to institutionalize what we're doing so that when people leave everything doesn't fall apart". Similarly, another respondent described how informal commitments are problematic, especially when coupled with a perceived high staff turnover within athletics, stating: "You're making a little bit of progress in terms of getting some people on board, and then again, unfortunately he left athletics." Additionally, the interviews suggest not all of what is disclosed on the STARS report is the case in practice. Specifically, three of the 12 institutions included within the sample referred to the athletic department no longer being a member of their university-wide sustainability committee whether that be due to personnel changes or a shift in the approach of the coordinating council.

The sample of 12 universities included within this study also implemented different variations of shared governance. While all 12 universities convened a coordinating council, only seven universities implemented a subcommittee structure that fed into the coordinating council, thus adopting a true councilor model of shared governance. Additionally, seven of the 12 universities implemented an appointee system for shared governance representatives, while six preferred to secure shared governance representation through voluntary commitments. Most of the university-level councils were coordinating councils, while others were advisory councils. Similarly, most of the councils involved athletics within the coordinating council, while others were involved within thematic subcommittees. On one hand, these findings reify previous research (see [20]), which provides evidence of the varying scopes and remits of environmental committees. On the other hand, however, the variation in shared sustainability governance systems supports Lapworth's [57] proposition that effective models of shared governance require diversity and flexibility to suit context-specific character and needs. 


\subsection{Shared Sustainability Governance as a Compensation for Loose Coupling}

Sustainability office personnel share a number of benefits to engage athletic departments in shared sustainability governance. Functionally, even at the university level, shared sustainability governance serves as a conduit for collaboration whereby a diverse group of people and departments come together to create sustainable solutions. One respondent explained how the functional capability of the coordinating council and the resulting diverse thinking, in many ways, encapsulates the very notion of sustainability "in a nutshell". Other practical examples have also been shared. For example, one respondent was able to draw on scenarios where the athletic department had tabled possible solar and stormwater management projects through the coordinating council, which sparked a number of possible inter-departmental collaborations. In essence, this respondent felt that engagement in the coordinating council was helping the athletic department with their future sustainability plans. Again, the fact that university-level models of governance provide opportunities to table department-specific problems is another example of the varying scopes and remits of environmental committees [18,44]. Furthermore, the fact that sustainability problems are being tabled in strategic-level meetings provides evidence of the loose coupling of sustainability practices across university departments.

Beyond the direct effects of collaboration, shared sustainability governance is seen as critical to mitigating the loss of control that the decentralized, loosely coupled structures within higher education promote. Specifically, one sustainability office representative stated:

A lot of times athletics can feel like its own separate world because they are funded differently and all that. But they are still a part of the university. So I think having them be a part of a larger sustainability committee helps them realize being bold and savvy should translate over to athletics as well.

Accordingly, these findings reify the work of McCullough, Kellison, and Wendling [30], who suggest cross-functional sustainability teams provide a bridge with university-wide goals through formal, joint decision-making processes. Similarly, shared governance provides an opportunity for universities to operationalize sustainability as a legitimate bonding mechanism, which Bstieller et al. [64] suggest is made possible by how shared governance enables organizations to adapt to new circumstances. After all, as one respondent claimed, athletic departments are "not a separate wing that can go off on their own".

Athletic department involvement in shared sustainability governance enables, as Orton and Weick [4] suggest, a genuine reaffirmation of shared values. As an example, one respondent claimed how securing commitments from the athletic department to the coordinating council "shows that they value the campus values" and are "trying to support a larger vision of the university". Moreover, another respondent described the sense of having "a unified presence" where all major functions of the university were "on the same page" as the main benefit of engaging the athletic department within the coordinating council. Subsequently, shared sustainability governance likely creates assumptions among non-athletic department staff that attendance is in some way indicative of Meyer and Rowan's [82] notion of "the logic of confidence and good faith", which creates the assumption that departments are performing their tasks and responding to their responsibilities correctly.

Sustainability office personnel also consider how a shared vision helps athletic departments, and other university departments for that matter, in identifying the potential synergies and leverage points of sustainability. In turn, these opportunities foster a sense of motivation toward sustainability action, which one respondent summarized as an emergent perspective on the "direction for how and what type of action to take". Furthermore, another respondent suggested the coordinating council provides the athletic department with the drive to "get ahead and stay ahead" with peers on campus, which leverages the competitive edge that is synonymous with athletics competition. As such, shared sustainability governance in this context is active in promoting a common understanding of goals [62], as well as coordinating goals and skills between partners [63]. Additionally, reaffirming shared values 
is critical to creating a level of responsiveness to sustainability, which, in this domain, supports coupling across the university.

Sharing values and perspectives is not one-directional. In fact, a number of respondents discussed how having the athletic department represented in the coordinating committee facilitates a deeper appreciation of the unique challenges faced by athletic programs. The following passage from one of the respondents embodies this mutually beneficial process:

We understand athletics has special needs and concerns, but we might not fully understand what those concerns are. So to have them at the table, it's great. So for example, just turf, our baseball fields are turf. So for sustainability it reduces water I guess and pesticide use because it's not real grass. But that wasn't their only reason for getting it, it was because we can't compete with southern schools because it's cold and shitty, you know, up here in spring. So we have to have artificial turf in order for our fields not to flood.

Similarly, another respondent discussed how a lack of involvement by several campus constituents with the athletic department, including students, faculty, and staff, often leads to misinformed perceptions of decision-making within athletics, to which this same respondent claimed:

Perhaps there may be an actual reason why the stadium lights are on all night long and there's no game. Maybe there's an actual reason. Like they're doing construction in there or something like that. And those kind of things come up in meeting and people were actually getting an answer, and they were like 'Right. OK. That makes sense.'

Accordingly, shared sustainability governance is active in reducing information asymmetry [61] and helping to prevent misunderstandings between governance members [62]. As one respondent summarized, "it makes the athletic department more personable", which provides a platform from which to build trusting relationships and, potentially, successful outcomes [66].

Yet, overall, shared sustainability governance appears to compensate for the decentralized nature of university structures, which makes sustainability a discretionary endeavor. To do so, shared sustainability governance enhances leadership around specific targets by reaffirming with the athletic department the value of sustainability.

\section{3. 'A Perfect Storm': Supplementing Shared Sustainability Governance}

Despite athletic department involvement in shared sustainability governance furnishing a number of compensatory benefits, the benefits are neither uniform nor absolute. As an example, collaboration was understood as a benefit by some, but by others collaboration was mostly one-sided. On the topic of collaboration between the athletic department and other university departments or campus constituents, one respondent replied that most of these collaborations are "people reaching out and engaging them [the athletic department] and it's not happening the other way yet". Furthermore, another respondent expressed their frustration by stating how they were "getting participation on a campus-wide basis from athletics, but not seeing a whole lot within the athletics department just yet". So, there is a sense that athletic departments are, in some ways, honoring the commitment to attending coordinating council meetings, but not necessarily converting this commitment into action. In this sense, the shared sustainability governance structures represent an epistemic community where actors share basic causal beliefs and normative values [83]. However, as Newig, Günther, and Pahl-Wostl [84] argue, participation in these communities does not necessarily involve the same level of interest in the problem at stake, which in this case is sustainability.

Similarly, the coercive nature of appointment-based engagement in shared sustainability governance is likely a step too far for some athletic departments. As one respondent explained:

They see the benefit, but I think it's still at the point where we're making them do something. So I think it's been a long time where I think that's where we're perceived as we're telling them to do something rather than working with them. 
Herein lies one of the challenges presented by forcing attention toward specific targets or goals within a decentralized system. By forcing athletic department attention toward sustainability, athletics personnel perhaps feel constrained to operate within the parameters of the university. Fittingly, another sustainability office representative used a sporting metaphor to effectively relate this thought by suggesting that the athletic department was "sort of playing the game and they're on the field. I'm not sure if they've really realized what the end goal is". Such a quandary leaves some sustainability office personnel increasingly frustrated in their attempts to help athletic departments realize the full extent to which sustainability creates value. To this end, one respondent claimed that "it is a nut that we have officially yet to crack and even with athletics being a part of the committee on sustainability they weren't necessarily actively pushing for sustainable practices in athletics".

Ultimately, the overriding consensus among sustainability office personnel interviewed in this study was that shared sustainability governance involvement only stands to enhance commitment when used in concert with other change levers. This sentiment was most accurately explained by one respondent who described a scenario whereby the university has "support from the top down and the bottom up, and then you have some champions in the middle that helps to connect that. It's rare to find that, to find all of those factors together in the same institution, a perfect storm." Figure 3 is a visual representation of the change levers the respondents disclosed, which either they have successfully deployed or that they feel would be a success given the complexities of engaging athletic departments in the sustainability journey.

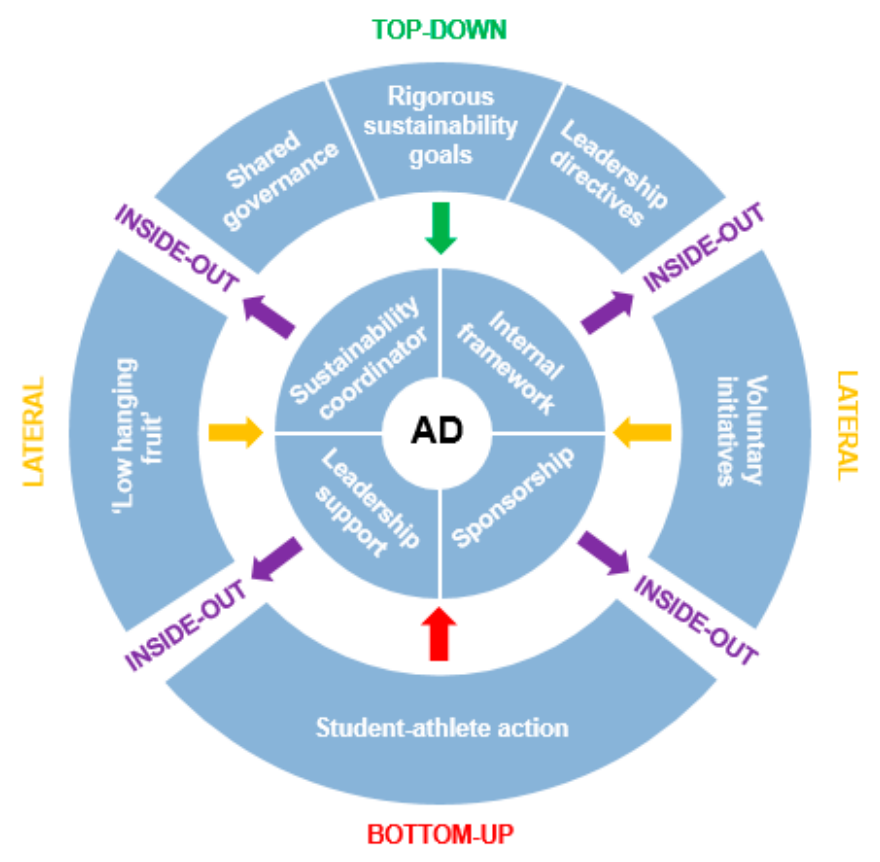

Figure 3. Levers for forcing athletic department attention toward sustainability.

Casper and Pfahl [19] suggest "environmental activities blur lines between distinct management functions making it both a top-down and bottom-up issue at the same time" (p. 24). Figure 3 embodies the notion of the 'perfect storm' by organizing the disclosed change levers through not only a top-down and bottom-up approach, but a multidimensional, all-angles approach. Specifically, there are strategic moves that the university could enforce in a top-down manner, or whereby a critical mass could focus attention through bottom-up endeavors. Likewise, there are strategic moves that the university could introduce to incentivize lateral collaboration or involvement in sustainability, as well as measures the athletic department could activate from an inside-out perspective. As such, the identification of these supplemental change levers represent the "nonobvious sources of order that administrators can use to 
influence dispersed organizations" [4] (p. 211). Table 1 provides additional context and supporting quotations for each of the proposed change levers.

Table 1. Levers for forcing athletic department attention toward sustainability.

\begin{tabular}{|c|c|c|}
\hline Lever & Direction & Representative Quotation \\
\hline $\begin{array}{l}\text { Rigorous } \\
\text { sustainability } \\
\text { goals }\end{array}$ & Top-down & $\begin{array}{l}\text { Until all sustainability is just incorporated into every single unit or until out climate } \\
\text { commitments have some sort of teeth behind them and saying you must do it. } \\
\text { I think the opportunity we've had is just applying these increasingly rigorous } \\
\text { sustainability goals for all facilities to athletics, which sort of brings them along in a } \\
\text { way that maybe they haven't called out for themselves. }\end{array}$ \\
\hline $\begin{array}{l}\text { Leadership } \\
\text { directives }\end{array}$ & Top-down & $\begin{array}{l}\text { My hope would be that the department's priorities are synced with the university's } \\
\text { priorities, and values, and one of those is sustainability. So it is my hope that would } \\
\text { filter down. }\end{array}$ \\
\hline $\begin{array}{l}\text { 'Low-hanging } \\
\text { fruit' }\end{array}$ & Lateral & $\begin{array}{l}\text { I think there's an interest within waste management and recycling and composting. I } \\
\text { say that just because that's the thing we spend the most time talking about and folks } \\
\text { seem to get the most excited about. We do have a lot of low-hanging fruit } \\
\text { opportunities there within that realm. So that might be one sort of focal area where I } \\
\text { can sort of see a little bit more traction with them. }\end{array}$ \\
\hline $\begin{array}{l}\text { Voluntary } \\
\text { initiatives }\end{array}$ & Lateral & $\begin{array}{l}\text { We are also working on a program that is in-house that allows departments to sign up } \\
\text { to make their travel carbon neutral or by helping the university to reduce greenhouse } \\
\text { emissions through efficiency projects on campus. We are hoping that by using } \\
\text { programs like this it will allow departments and events to advertise the fact that they } \\
\text { are doing something that is carbon neutral and get credit for that, that will apply } \\
\text { pressure, peer pressure. }\end{array}$ \\
\hline \multirow[t]{2}{*}{$\begin{array}{l}\text { Internal } \\
\text { framework }\end{array}$} & \multirow[t]{2}{*}{ Inside-out } & $\begin{array}{l}\text { I would say the responsibility of the university writ large with sustainability would be } \\
\text { to create a culture where somebody on the inside of athletics says, 'you know what, } \\
\text { sustainability is really part of what we do and we need to call it out here.' }\end{array}$ \\
\hline & & $\begin{array}{l}\text { I think having a framework for them can sort of clearly define their expectations, their } \\
\text { strategies, to make athletics more sustainable. }\end{array}$ \\
\hline \multirow[t]{2}{*}{$\begin{array}{l}\text { Leadership } \\
\text { support }\end{array}$} & \multirow[t]{2}{*}{ Inside-out } & $\begin{array}{l}\text { I would think it would have to be our Athletics Director wanting sustainability to be } \\
\text { part of what they do. And that might happen through conversations with our } \\
\text { President.... But if it became part of the leadership team and one of their goals was } \\
\text { around sustainability, then I could imagine a greater involvement with athletics. }\end{array}$ \\
\hline & & $\begin{array}{l}\text { But I think it they are going to go all in, then it's going to take that top level leadership } \\
\text { to say, 'look, this is really important'. We want a culture of winning and winning } \\
\text { games, but we're not just winning on the field - we're winning off the field. }\end{array}$ \\
\hline \multirow[t]{2}{*}{$\begin{array}{l}\text { Sustainability } \\
\text { coordinator }\end{array}$} & \multirow[t]{2}{*}{ Inside-out } & $\begin{array}{l}\text { I think it would take dedicated time from the current staff. We can help support from } \\
\text { the outside, but with larger departments on campus there are certain sub-cultures in } \\
\text { these departments. And so until those sub-cultures recognize sustainability as part of } \\
\text { their daily practices, I think any change that comes from the outside will only be } \\
\text { temporary. }\end{array}$ \\
\hline & & $\begin{array}{l}\text { For the athletics department to become more sustainable and really push that, honestly } \\
\text { it's having someone that's dedicated } 24 / 7 \text { to the operations of our athletics department. }\end{array}$ \\
\hline Sponsorship & Inside-out & $\begin{array}{l}\text { The other would be sponsorship. Nothing has come to fruition yet, but that is } \\
\text { something that if it did happen, that would be a much easier way for athletics, } \\
\text { especially the operations, to really make it a priority. That would be a game changer. }\end{array}$ \\
\hline \multirow{3}{*}{$\begin{array}{l}\text { Student-athlete } \\
\text { action }\end{array}$} & \multirow{3}{*}{ Bottom-up } & $\begin{array}{l}\text { Two years ago I had a student working on zero waste. They worked a lot on reducing } \\
\text { waste and raising awareness on campus... Our Athletics Director was engaged in that } \\
\text { and he helped and advocated for building composting into some of the athletics events } \\
\text { and recycling. So that connection, that student-to-director at a smaller scale and not as } \\
\text { part of the large group was probably more impactful than coming to the large group. }\end{array}$ \\
\hline & & $\begin{array}{l}\text { I think student interest goes a long, long way. And so if some of the sports teams are } \\
\text { interested in this, saying that it is a huge problem for the future of the sport, that would } \\
\text { go a long way. I think that goes farther than anything I can say or do as a staff member. }\end{array}$ \\
\hline & & $\begin{array}{l}\text { I think on a college campus the more the student are invested in, involved in } \\
\text { something, the better chance of success we have. }\end{array}$ \\
\hline
\end{tabular}




\subsection{Limitations of the Study}

Using AASHE STARS as a means by which to identify cases of athletic department engagement in shared sustainability governance structures presents challenges in reaching the population of interest. First, using AASHE STARS in the context of this study did limit the sample population to universities who chose to complete the reporting process. Second, AASHE STARS, like the majority of assessment-based reporting processes, provides a snapshot in time, and what this study revealed was that shared sustainability governance structures, models, and membership are in a constant state of flux.

In addition, compensations proved a relevant voice to use within the loosely coupled context of athletic departments and wider university sustainability goals and priorities, as most respondents within this study considered this level of coupling to be a sub-optimal state. Yet, perhaps loose coupling in this context is more advantageous than disadvantageous. As one respondent claimed: "The university is so diffuse. There is a lot of autonomy. Ideas are coming from departments. How can we do $x, y$ and $z$ ? There is no top-down pressure being applied." In such a scenario, the coordinating council empowers the representatives to go back to their departments and say this is worthwhile, rather than returning simply to communicate and provide an update on the university's overall strategy and goals. Furthermore, Haas [83] suggests the best institutional structure for dealing with complex policy environments is, in fact, loose and decentralized, but also dense networks. Haas [83] suggests network density enables the quick relay of information, and that the loosely coupled and decentralized nature of such networks allows the inactivity of one actor not to jeopardize the efforts of the whole. Accordingly, while the voice of compensations provides a sufficiently narrow theoretical guide for this study, under-utilizing other loose coupling voices (e.g., the voice of direct effects or organizational outcomes) presents a limitation in terms of the insights generated.

\section{Conclusions}

Theoretically, this study provides further evidence of the dialectical nature of loose coupling within the higher education context, and, more specifically, between a more contemporary coupling context than the historical focus on interdependencies between administrators and faculty. The study supports how athletic departments demonstrate at least a basic level of engagement in sustainability that mirrors the wider university (i.e., determinacy). Yet, the varying levels of commitment from athletic departments to shared governance structures demonstrate a simultaneous level of independence between athletics and the university more generally. Athletic departments highlight the challenges universities face in reflecting institutional commitments across all aspects of the campus, which the Rio+20 People's Sustainability Treaty on Higher Education [85] suggests spans campus management, curriculum, research, and student and community engagement activities. As such, athletic departments are a key internal stakeholder for universities to engage in order to achieve a whole-of-institution approach and commitment to sustainability.

The insight generated through this study points to a number of practical implications for sustainability office personnel. Likewise, such implications are potentially useful for athletic department staff who identify as sustainability leads, and who wish to create greater buy-in internally from colleagues. First, justification should be made for athletic department involvement in shared sustainability governance. For example, does the athletic department boast high visibility as well as being a high-impact campus department? If yes, then athletics likely deserves a seat at the table as a critical cog in the twofold responsibility of universities to sustainability (i.e., as an operation to be changed, and as a change agent). Second (and dependent upon the model of shared governance being deployed), is where exactly the athletics departments are engaged in the system. Athletics, as understood through several of the respondents within this study, has the potential to be the 'sustainable front porch' of the university. However, depending on the context, there might be more merit in engaging the athletics department through a thematic subcommittee where tighter coupling exists, and where greater leverage points and synergies can be pitched to optimize levels of engagement. 
Third, identifying the most appropriate person to represent the athletics department is crucial, as it is this individual who will serve as a more formal bridge with the university's sustainability goals. Fourth (and connected to the third practical implication), is the extent to which the shared sustainability governance system will focus the attention of the athletic department. In other words, who will represent the athletic department and will this representative be appointed or approached with a request to voluntary join the coordinating council and/or thematic subcommittee? Such decisions are not solely a matter for athletic departments. However, appointing the Director of Athletics to the coordinating council does not automatically amount to an institutionalized commitment. Rather, sustainability office personnel should match as best they can the personal interest and passion for sustainability of existing athletic department staff with an appropriate means by which to make this engagement routine. Recognizing the relatively high turnover of staff within athletics positions, those charged with heading up shared sustainability governance systems should perhaps focus on succession planning. For example, campuses that address leadership continuity as well as providing training and advice to new officers are more successful at governance [86].

Finally, and most importantly, efforts to engage athletic departments in shared sustainability governance should be supplemented by other change levers. Ultimately, the aspirational condition is to achieve a 'perfect storm' that calls for a combination of top-down, bottom-up, lateral, or inside-out tactics. Yet, while this study suggests that securing an institutionalized commitment is a complex matter, further research is necessary to tease out the importance and effectiveness of multi-dimensional efforts to engage athletics departments in sustainability action. For example, an in-depth case study of a university whose athletics department is immersed in this multi-dimensional approach would elucidate the relative importance of each of the strategic levers. More specifically, a scarcity of research exists that understands the role of student athletes as catalysts for athletics department sustainability action, and further qualitative research could generate a rich understanding of the role of sustainability in the dual identity of student athletes on university campuses in the United States.

Author Contributions: Conceptualization, M.B.; data curation M.B.; formal analysis, M.B.; methodology, M.B.; supervision, K.S.B.; writing - original draft, M.B.; writing - review and editing, K.S.B., J.M.C., M.B.E, D.S.S. and G.J.J.

Funding: This research received no external funding.

Conflicts of Interest: The authors declare no conflict of interest.

\section{References}

1. Krizek, K.J.; Newport, D.; White, J.; Townsend, A.R. Higher education's sustainability imperative: How to practically respond? Int. J. Sustain. High. Educ. 2012, 13, 19-33. [CrossRef]

2. Reponen, T. Is leadership possible at loosely coupled organizations such as universities? High. Educ. Policy 1999, 12, 237-244. [CrossRef]

3. OECD. Changing patterns of governance in higher education. In Education Policy Analysis; OECD: Paris, France, 2003; Available online: https://www.oecd.org/education/skills-beyond-school/35747684.pdf (accessed on 12 September 2019).

4. Orton, J.D.; Weick, K.E. Loosely coupled systems: A reconceptualization. Acad. Manag. Rev. 1990, 15, 203-223. [CrossRef]

5. Meyer, J.W.; Rowan, B. The structure of educational organizations. In Schooling in a Social Context, 3rd ed.; Ballantine, J.H., Spade, J.Z., Eds.; Pine Forge Press: Lose Angeles, CA, USA, 2008; pp. 217-226.

6. Hardy, C.; Langley, A.; Mintzberg, H.; Rose, J. Strategy formation in the university setting. Rev. High. Educ. 1983, 6, 407-433. [CrossRef]

7. Birnbaum, R. How Academic Leadership Works; Jossey-Bass: San Francisco, CA, USA, 1992.

8. Blackburn, R.T.; Lawrence, J.H. Faculty at Work; The John Hopkins Press: Baltimore, MD, USA, 1995.

9. Del Favero, M.; Bray, N.J. Herding cats and big dogs: Tensions in the faculty-administrator relationship. In Higher Education: Handbook of Theory and Research; Paulsen, M.B., Perna, L.W., Eds.; Springer: Dordrecht, The Netherlands, 2010; Volume 25. 
10. Peterson, M.W.; White, T.H. Faculty and administrator perceptions of their environments: Different views of different models of organization? Res. High. Educ. 1992, 33, 177-204. [CrossRef]

11. Chandler, J.C., III. Bridging the Chasm: Emerging Model of Leadership in Intercollegiate Athletics Governance. Ph.D. Theis, The University of Las Vegas Nevada, Las Vegas, NV, USA, December 2011. Available online: https://digitalscholarship.unlv.edu/cgi/viewcontent.cgi?referer=https://scholar.google.com/ \&httpsredir $=1$ \&article $=2375 \&$ context=thesesdissertations (accessed on 12 September 2019).

12. Hanford, G.H.; Greenberg, M. We should speak the "awful truth" about college sports ... or does the public like the status quo? Chron. High. Educ. 2003, 49, 10-13.

13. Sack, A.L. College sport and the student athlete. J. Sport Soc. Issues 1987, 11, 31-48. [CrossRef]

14. Suggs, W. Old challenges and new opportunities for studying the financial aspects of intercollegiate athletics. N. Dir. High. Educ. 2009, 148, 11-22. [CrossRef]

15. Duderstadt, J.J. Intercollegiate Athletics and the American University: A University President's Perspective; The University of Michigan Press: Ann Arbor, MI, USA, 2009.

16. Sanderson, A.R.; Siegfried, J.J. The case for paying college athletes. J. Econ. Perspect. 2015, 29, 115-138. [CrossRef]

17. Bass, J.R.; Schaeperkoetter, C.C.; Bunds, K.S. The 'Front Porch': Examining the Increasing Interconnection of University and Athletic Department Funding; ASHE higher education report; John Wiley \& Sons: Hoboken, NJ, USA, 2015; Volume 41.

18. Casper, J.M.; Pfahl, M.E.; McSherry, M. Athletics department awareness and action regarding the environment: A study of NCAA athletics department sustainability practices. J. Sport Manag. 2012, 26, 11-29. [CrossRef]

19. Casper, J.M.; Pfahl, M.E. Environment sustainability practices in U.S. NCAA Division II athletics departments. Int. J. Event Manag. Res. 2015, 10, 12-36.

20. Casper, J.M.; Pfahl, M.E.; McCullough, B.P. Intercollegiate sport and the environment: Examining fan engagement based on athletics department sustainability efforts. J. Issues Intercoll. Athl. 2014, 7, 65-91.

21. Ferrer-Balas, D.; Adachi, J.; Banas, S.; Davidson, C.I.; Hoshikoshi, A.; Mishra, A.; Motodoa, Y.; Onga, M.; Ostwald, M. An international comparative analysis of sustainability transformation across seven universities. Int. J. Sustain. High. Educ. 2008, 9, 295-316. [CrossRef]

22. Adams, R.; Martin, S.; Boom, K. University culture and sustainability: Designing and implementing an enabling framework. J. Clean. Prod. 2018, 171, 434-445. [CrossRef]

23. Asif, M.; Searcy, C.; Zutshi, A.; Fisscher, O.A.M. An integrated management systems approach to corporate social responsibility. J. Clean. Prod. 2013, 56, 7-17. [CrossRef]

24. Viebahn, P. An environmental management model for universities: From environmental guidelines to staff involvement. J. Clean. Prod. 2002, 10,3-12. [CrossRef]

25. Meyer, H.-D.; Rowan, B. Institutional analysis and the study of education. In The New Institutionalism in Education; Meyer, H.-D., Rowan, B., Eds.; SUNY Press: Albany, NY, USA, 2006; pp. 1-13.

26. De Boer, H.F.; Enders, J.; Leisyte, L. Public sector reform in Dutch higher education: The organizational transformation of the university. Public Adm. 2007, 85, 27-46. [CrossRef]

27. Velazquez, L.; Munguia, N.; Platt, A.; Taddei, J. Sustainable university: What can be the matter? J. Clean. Prod. 2006, 14, 810-819. [CrossRef]

28. Adams, C.A. Sustainability reporting and performance management in universities: Challenges and benefits. Sustain. Account. Manag. Policy J. 2013, 4, 384-392. [CrossRef]

29. Pfahl, M.E. Strategic issues associated with the development of internal sustainability teams in sport and recreation organization: A framework for action and sustainable environmental performance. Int. J. Sport Manag. Rec. Tour. 2010, 6, 37-61. [CrossRef]

30. McCullough, B.P.; Kellison, T.; Wendling, E. Formation and function of a collegiate athletics sustainability committee. J. Amat. Sport 2018, 4, 52-81. [CrossRef]

31. ISCN Secretariat. International Sustainable Campus Network (ISCN): Taking Your Campus Sustainability Program to a Global Stage. In Proceedings of the 4th UNICA Green Academic Footprint Workshop, Brussels, Belgium, 27-28 March 2014; Available online: http://www.unica-network.eu/sites/default/files/ ISCN\%20Overview_20140327_for\%20UGAF_cg.pdf (accessed on 12 September 2019).

32. Swearingen White, S. Campus sustainability plans in the United States: Where, what, and how to evaluate? Int. J. Sustain. High. Educ. 2014, 15, 228-241. [CrossRef]

33. Second Nature. History. Available online: https://secondnature.org/history/ (accessed on 12 September 2019). 
34. Swearingen White, S. Early participation in the American College and University Presidents' Climate Commitment. Int. J. Sustain. High. Educ. 2009, 10, 215-227. [CrossRef]

35. Tilbury, D. Higher education for sustainability: A global overview of commitment and progress. High. Educ. World 2011, 4, 18-28.

36. Stephens, J.C.; Hernandez, M.E.; Román, M.; Graham, A.C.; Scholz, R.W. Higher education as a change agent for sustainability in different cultures and contexts. Int. J. Sustain. High. Educ. 2008, 9, 317-338. [CrossRef]

37. Hottle, T.A.; Bilec, M.M.; Brown, N.R.; Landis, A.E. Toward zero waste: Composting and recycling for sustainable venue based events. Waste Manag. 2015, 38, 86-94. [CrossRef]

38. Klein-Banai, C.; Theis, T.L. An urban university's ecological footprint and the effect of climate change. Ecol. Indic. 2011, 11, 857-860. [CrossRef]

39. Dmochowski, J.E.; Garofalo, D.; Fisher, S.; Greene, A.; Gambogi, D. Integrating sustainability across the university curriculum. Int. J. Sustain. High. Educ. 2016, 17, 652-670. [CrossRef]

40. Dyer, G.; Dyer, M. Strategic leadership for sustainability by higher education: The American College \& University Presidents' Climate Commitment. J. Clean. Prod. 2017, 140, 111-116.

41. Salvioni, D.; Franzoni, S.; Cassna, R. Sustainability in the higher education system: An opportunity to improve quality and image. Sustainability 2017, 9, 914-942. [CrossRef]

42. Ralph, M.; Stubbs, W. Integrating environmental sustainability into universities. High. Educ. 2014, 67, 71-90. [CrossRef]

43. Epstein, M.J. Implementing corporate sustainability: Measuring and managing social and environmental impacts. Strateg. Financ. January 2008, 25-31.

44. Pfahl, M.E.; Casper, J.M.; Trendafilova, S.; McCullough, B.P.; Nguyen, S.N. Crossing boundaries: An examination of sustainability department and athletics department collaboration regarding environmental issues. Commun. Sport 2015, 3, 27-56. [CrossRef]

45. Glassman, R.B. Persistence and loose coupling in living systems. Behav. Sci. 1973, 18, 83-98. [CrossRef]

46. Bossert, S.; Dwyer, D.; Rowan, B.; Lee, G. The instructional management role of the principal. Educ. Adm. Q. 1982, 18, 34-64. [CrossRef]

47. Brusoni, S.; Prencipe, A. Managing knowledge in loosely coupled networks: Exploring the links between product and knowledge dynamics. J. Manag. Stud. 2001, 38, 1019-1035. [CrossRef]

48. Weick, K.E. Educational organizations as loosely coupled systems. Adm. Sci. Q. 1976, 21, 1-19. [CrossRef]

49. Goldspink, C. Rehtinking educational reform: A loosely coupled and complex systems perspective. Educ. Manag. Adm. Leadersh. 2007, 35, 27-50. [CrossRef]

50. Tierney, W.G.; Minor, J.T. A cultural perspective on communications and governance. In Restructuring Shared Governance in Higher Education: New Directions for Higher Education; Tierney, W.G., Lechuga, V.M., Eds.; Jossey-Bass: San Francisco, CA, USA, 2004; pp. 85-94.

51. Tricker, R.I. International Corporate Governance; Prentice Hall: Englewood Cliffs, NJ, USA, 1984.

52. Olson, G.A. Exactly What Is 'Shared Governance'? The Chronicle of Higher Education: Washington, DC, USA; Available online: https://www.chronicle.com/article/Exactly-What-Is-Shared/47065 (accessed on 12 September 2019).

53. Lechuga, V.M. Exploring current issues on shared governance. In Restructuring Shared Governance in Higher Education; Tierney, W.G., Lechuga, V.M., Eds.; Jossey-Bass: San Francisco, CA, USA, 2004; pp. 95-98.

54. Cramer, S.F.; Mozlin, R. Sharing shared governance: The benefits of systemness. In Shared Governance in Higher Education: Demands, Transitions, Transformations; Cramer, S.F., Ed.; SUNY Press: Albany, NY, USA, 2017; pp. 89-116.

55. SUNY Shared Governance Transformation Team. Preamble to Shared Governance Toolkit Guidelines. 2011. Available online: https://system.suny.edu/media/suny/content-assets/documents/powerofsuny/the-processof-the-power-of-suny/SharedGovernance_20110408.pdf (accessed on 12 September 2019).

56. Bejou, D.; Bejou, A. Shared governance and punctuated equilibrium in higher education: The case for student recruitment, retention, and graduation. J. Relatsh. Market. 2012, 11, 248-258. [CrossRef]

57. Lapworth, S. Arresting decline in shared governance: Towards a flexible model for academic participation. High. Educ. Q. 2004, 58, 299-314. [CrossRef]

58. Yanko, J.R.; Hardt, M.; Bradstock, J. The clinical nurse specialist role in shared governance. Crit. Care Nurs. Q. 1995, 18, 86-90. [CrossRef]

59. Bernreuter, M. The other side of shared governance. J. Nurs. Adm. 1993, 23, 12-14. [CrossRef] 
60. Hess, J.R. Shared governance: Innovation or imitation? Nurs. Econ. 1994, 12, 28-34.

61. Saxton, T. The effects of partner and relationship characteristics on alliance outcomes. Acad. Manag. J. 1997, $40,443-461$.

62. Asmus, D.; Griffin, J. Harnessing the power of your suppliers. McKinsey Q. 1993, 3, 63-79.

63. Lawson, B.; Peterson, K.J.; Cousins, P.D.; Handfield, R.B. Knowledge sharing in interorganizational product development teams: The effect of formal and informal socialization mechanisms. J. Prod. Innov. Manag. 2009, 26, 156-172. [CrossRef]

64. Bstieler, L.; Hemmert, M.; Barczak, G. Trust formation in university-industry collaborations in the U.S. biotechnology industry: IP policies, shared governance, and champions. J. Prod. Innov. Manag. 2014, 32, 111-121. [CrossRef]

65. Anthony, M.K. Shared governance models: The theory, practice, and evidence. Online J. Nurs. Issues 2004, 9 , 138-157.

66. Burnside, B.; Witkin, L. Forging successful university-industry collaborations. Res.-Technol. Manag. 2008, 51, 26-30. [CrossRef]

67. De Vaus, D.A.; de Vaus, D. Research Design in Social Research; Sage: Thousand Oaks, CA, USA, 2001.

68. Babbie, E. The Practice of Social Research, 13th ed.; Cengage Learning: Boston, MA, USA, 2012.

69. Remler, D.K.; Van Ryzin, G.G. Research Methods in Practice: Strategies for Description and Causation; Sage: Thousand Oaks, CA, USA, 2011.

70. White, G.B.; Koester, R.J. STARS and GRI: Tools for campus greening strategies and prioritizations. Sustainability 2012, 5, 100-106. [CrossRef]

71. NCES. Digest of Education Statistics: 2016. Available online: https://nces.ed.gov/programs/digest/d16/ch_3. asp (accessed on 12 September 2019).

72. Palinkas, L.A.; Horwitz, S.M.; Green, C.A.; Wisdom, J.P.; Duan, N.; Hoagwood, K. Purposeful sampling for qualitative data collection and analysis in mixed method implementation research. Adm. Policy Ment. Health 2015, 42, 533-544. [CrossRef]

73. Barrow, J.M.; Khandhar, P.B. Research Ethics. Available online: https://www.ncbi.nlm.nih.gov/books/ NBK459281/ (accessed on 12 September 2019).

74. Guest, G.; Bunce, A.; Johnson, L. How many interviews are enough? An experiment with data saturation and variability. Field Methods 2006, 18, 59-82. [CrossRef]

75. Creswell, J.W.; Plano Clark, V.L. Designing and Conducting Mixed Methods Research, 3rd ed.; Sage: Thousand Oaks, CA, USA, 2011.

76. Shenton, A.K. Strategies for ensuring trustworthiness in qualitative research projects. Educ. Inf. 2004, 22, 63-75. [CrossRef]

77. Fisher, R.J. Social desirability bias and the validity of indirect questioning. J. Consum. Res. 1993, 20, 303-315. [CrossRef]

78. Saldaña, J. The Coding Manual for Qualitative Researchers; Sage: Thousand Oaks, CA, USA, 2015.

79. Braun, V.; Clarke, V. Using thematic analysis in psychology. Qual. Res. Psychol. 2006, 3, 77-101. [CrossRef]

80. Van Gigch, J.P. Applied General Systems Theory, 2nd ed.; Harper: New York, NY, USA, 1978.

81. Skyttner, L. General Systems Theory: Ideas and Applications; World Scientific: River Edge, NJ, USA, 2001.

82. Meyer, J.W.; Rowan, B. Institutionalized organizations: Formal structure as myth and ceremony. Am. J. Sociol. 1977, 83, 340-363. [CrossRef]

83. Haas, P.M. Addressing the global governance deficit. Global Environ. Polit. 2004, 4, 1-15. [CrossRef]

84. Newig, J.; Günther, D.; Pahl-Wostl, C. Synapses in the network: Learning in governance networks in the context of environmental management. Ecol. Soc. 2010, 15, 24. [CrossRef]

85. Rio+20. People's Sustainability Treaty on Higher Education. In Proceedings of the United Nations Conference on Sustainable Development, Rio de Janeiro, Brazil, 20-22 June 2012; Available online: https: //sustainabilitytreaties.org/draft-treaties/higher-education/ (accessed on 12 September 2019).

86. Lee, B. Campus leaders and campus senates. In Faculty in Governance: The Role of Senates and Joint Committees in Academic Decision Making; Birnbaum, R., Ed.; Jossey-Bass: San Francisco, CA, USA, 1991.

(C) 2019 by the authors. Licensee MDPI, Basel, Switzerland. This article is an open access article distributed under the terms and conditions of the Creative Commons Attribution (CC BY) license (http://creativecommons.org/licenses/by/4.0/). 